\title{
HUBUNGAN FREKUENSI KONSUMSI MAKANAN KARIOGENIK DAN PENGETAHUAN KESEHATAN GIGI DENGAN KARIES GIGI PADA ANAK SEKOLAH DASAR DI KOTA BENGKULU
}

\author{
Kamsiah*, Emy Yuliantini **, Kosma Heryati $^{* * *}$ \\ *Poltekkes Kemenkes Bengkulu, Dosen Jurusan Gizi Jl. Indragiri 3 Padang \\ **Poltekkes Kemenkes Bengkulu, Dosen Jurusan Gizi Jl. Indragiri 3 Padang \\ * Poltekkes Kemenkes Bengkulu, Dosen Jurusan Kebidanan Jl. Indragiri 3 Padang Harapan
}

Background. School age groups whose numbers are large enough and high enough teeth caries. One of the factors causing dental caries is a high consumption of cariogenic foods. According to the profile of the city of Bengkulu health, dental caries was ranked 15 of 21 patterns of disease outpatient clinic. Research Objectives. To Know the relationships and frequency of consumption of cariogenic dental health knowledge with dental caries in primary school children in the city of Bengkulu. Research Methods. Type of research is an observational study with cross-sectional research design. Subjects in this study were grade III-IV as many as 212 people Negeri 1, SD Negeri 4, SD Negeri 9, Bengkulu City Elementary School 74. The data analysis was performed with univariate and bivariate analysis, the use of statistics by using the Chi-square test and multivariate analysis with logistic regression statistical tests. Research. A total of $72.6 \%$ of respondents are cariogenic foods. Type of cariogenic foods are often consumed the sweets $(22 \%)$, chocolate $(20 \%)$ and ice cream $(14 \%)$. There were $33.5 \%$ of respondents were regular dental checks. More than half of respondents $(52.8 \%)$ were suffering from dental caries. Statistical test results obtained on disignifikan relationships between children with dental caries $(p=0.009)$. Children who are not regular dental memeriksaan 2.263 times likely to suffer from dental caries than children who regularly check their teeth. Obtained a significant relationship between the frequency of consumption of cariogenic foods with dental caries $(p=0.002)$. Children who frequently eat foods cariogenic 2.819 times likely to have dental caries than children who rarely eat cariogenic foods. Multivariate test results demonstrate knowledge of dental health is the most dominant factor affecting dental caries.

\begin{abstract}
Abstrak : Anak usia sekolah merupakan kelompok masyarakat yang jumlahnya cukup besar dan prevalensi karies giginya cukup tinggi. Salah satu faktor penyebab karies gigi adalah konsumsi makanan kariogenik yang tinggi. Menurut profil kesehatan kota Bengkulu, karies gigi berada di urutan ke 15 dari 21 pola penyakit pasien rawat jalan di puskesmas. Penderita terbesar berada pada umur 6-12 tahun (usia sekolah dasar) sebesar 117 orang. Tujuan Penelitian. Untuk Mengetahui hubungan frekuensi konsumsi makanan kariogenik dan pengetahuan kesehatan gigi dengan karies gigi pada anak Sekolah Dasar di Kota Bengkulu. Metode Penelitian. Jenis penelitian yang digunakan adalah penelitian observasional dengan rancangan penelitian cross sectional. Subjek pada penelitian ini adalah siswa kelas III-IV sebanyak 212 orang Negeri 1, SD Negeri 4, SD Negeri 9 , SD Negeri 74 Kota Bengkulu. Analisa data dilakukan dengan analisis univariat dan bivariat, penggunaan statistik dengan menggunakan uji Chi-Square serta analisis multivariat dengan uji statistik regresi logistik. Hasil Penelitian. Sebanyak 72,6\% responden mengaku sering mengkonsumsi makanan kariogenik. Jenis makanan kariogenik yang sering dikonsumsi yaitu permen (22\%), coklat $(20 \%)$ dan es krim (14\%). Terdapat 33,5\% responden yang teratur melakukan pemeriksaan gigi. Lebih dari setengah responden $(52,8 \%)$ yang menderita karies gigi. Hasil uji statistic diperoleh terhadap hubungan yang disignifikan antara pemeriksaan gigi anak dengan karies gigi $(\mathrm{p}=0,009)$. Anak yang tidak teratur memeriksaan gigi berpeluang 2,263 kali untuk menderita karies gigi dibandingkan anak yang teratur memeriksakan gigi. Diperoleh hubungan yang signifikan antara frekuensi konsumsi makanan kariogenik dengan karies gigi $(\mathrm{p}=0,002)$. Anak yang sering mengkonsumsi makanan kariogenik berpeluang 2,819 kali untuk mengalami karies gigi dibandingkan anak yang jarang mengkonsumsi makanan kariogenik. Hasil uji multivariat menunjukkan pengetahuan kesehatan gigi merupakan faktor yang paling dominan mempengaruhi karies gigi.
\end{abstract}

Kata Kunci: makanan kariogenik, pengetahuan kesehatan gigi, karies gigi 
Pertumbuhan dan perkembangan anak secara normal termasuk gigi dan mulutnya memerlukan dukungan nutrisi yang cukup dengan memperhatikan cara mengkonsumsi, jenis makanan dan waktu pemberiannya karena semua ini akan berpengaruh pada perkembangan kebersihan mulut dan kemungkinan timbulnya karies gigi (Mar hamiah dan Muliaty, 2002). Menurut Ju naidi (2004), keparahan karies gigi menyebabkan asupan makanan anak berkurang dan bila hal ini berlangsung lama akan berpengaruh terhadap status gizi anak. Anak usia sekolah merupakan kelompok masyarakat yang jumlahnya cukup besar dan prevalensi karies giginya cukup tinggi. Usia sekolah ini (5,5 sampai dengan 11 tahun) merupakan masa transisi pergantian gigi sulung ke gigi tetap (Tomasowa, 1995). Saat istirahat sekolah anakanak biasanya membeli makanan dan minuman di warung sekolah atau pedagang di depan sekolah. Minuman manis seperti pop es. es teh dan makanan manis seperti permen, es lilin dan kue-kue manis yang paling sering dibeli oleh murid. Hasil penelitian Sutatmi (1994) menunjukkan prevalensi karies gigi pada anak sekolah usia 6 sampai dengan 14 tahun sebesar 60 sampai dengan $80 \%$. Menurut survei kesehatan rumah tangga (SKRT) 2004, prevalensi karies gigi sebesar 74\%. Persentase ini masih jauh dari target gigi sehat WHO tahun 2000 untuk anak umur 5 sampai 6 tahun yaitu $50 \%$ bebas karies dan $90 \%$ bebas karies di tahun 2010 untuk umur 3 sampai 5 tahun. (DepKes RI, 2001)

Karies merupakan suatu penyakit jaringan keras gigi yang disebabkan oleh aktivitas suatu jasad renik dalam suatu karbohidrat yang dapat diragikan dan ditandai adanya demineralisasi jaringan keras gigi yang diikuti oleh kerusakan bahan organiknya (Kidd dan Bechal, 1992). Masalah ini akan menjadi lebih kompleks karena karies juga dipengaruhi oleh faktor lingkungan, konsumsi makanan, dan perilaku kebersihan gigi (Rahina, dkk, 2002). Makanan terutama dari jenis karbohidrat yang terselip di antara gigi, oleh kuman- kuman di mulut akan diubah menjadi asam yang meng-akibatkan permukaan email menjadi lunak dan terjadi karies gigi (Machfoedz dan Zein, 2005).

Menurut profil kesehatan kota Bengkulu, karies gigi berada di urutan ke 15 dari 21 pola penyakit pasien rawat jalan di puskesmas umur 5 sampai dengan 65 tahun. Berdasarkan data puskesmas bulan Januari-Maret 2011, data karies gigi di Puskesmas Pasar Bengkulu jumlah ratarata karies gigi pada umur 6-12 tahun sebesar 117 orang, dipuskesmas pasar ikan jumlah rata-rata karies gigi pada umur 6-12 tahun sebesar 93 orang, dipuskesmas sawah lebar rata-rata karies gigi umur 6-12 tahun sebanyak 46 orang, dan dipuskesmas betungan sebanyak 10 orang.

\section{BAHAN DAN CARA KERJA}

Jenis penelitian yang digunakan adalah penelitian observasional dengan rancangan penelitian cross sectional. Sampel pada penelitian sebanyak 212 orang anak. Pengambilan sampel dilakukan dengan cara proporsional dengan teknik Pervosive Sampling sehingga diperoleh sampel anak kelas III dan IV sebanyak 50 anak untuk setiap sekolah. Penelitian ini dilaksanakan di 4 (empat) Sekolah Dasar (SD) yang berada di Kota Bengkulu yaitu SD Negeri 1, SD Negeri 4, SD Negeri 9, SD Negeri 74. Subjek pada penelitian ini adalah murid kelas III - IV dengan kriteria inklusi sebagai berikut: Siswa terdaftar pada SD Negeri 1, SD Negeri 4, SD Negeri 9 , SD Negeri 74 Kota Bengkulu, Siswa kelas IIIIV, Anak tidak memakai kawat gigi.

Data Karies gigi diperoleh dengan melakukan pemeriksaan gigi pada anak sekolah dasar dengan bantuan seorang dokter gigi. Data Frekuensi konsumsi makanan kariogenik anak diperoleh melalui form food frequency yang ditanyakan pada sampel. Data Pengetahuan kesehatan gigi diperoleh dengan melakukan wawancara dengan kuesioner pada anak dibantu guru kelas. Data dianalisis dengan analisis univariat dan bivariat, penggunaan statistik 
dengan menggunakan uji Chi-Square serta analisis multivariat dengan uji statistik regresi logistik.

HASIL
Hasil penelitian disajikan dalam analisis univariat dari setiap variable independen dan dependen. Penyajian dilanjutkan dengan hasil analisis bivariat dan multivariat yang bertujuan untuk mengetahui hubungan antara variabel independen dengan variable dependenen.

Tabel 1. Distribusi Responden Berdasarkan Karakteristik Anak Sekolah Dasar Negeri Kota Bengkulu Bulan Juli 2011

\begin{tabular}{lcc}
\hline Jenis Variabel & $\mathrm{N}$ & $\%$ \\
\hline Jenis Kelamin & & 47,6 \\
Laki-laki & 101 & 52,4 \\
Perempuan & 111 & 66,5 \\
Umur & & 33,5 \\
$8-10$ tahun & 141 & 33,5 \\
$>10-12$ tahun & 71 & 66,5 \\
Pemeriksaan gigi & & \\
Teratur & 71 & 72,6 \\
Tidak teratur & 141 & 27,4 \\
Frekuensi makanan kariogenik & & \\
Sering & 154 & 70,8 \\
Tidak sering & 58 & 29,2 \\
Pengetahuan & & 52.8 \\
Baik & 150 & 47.2 \\
Tidak baik & 62 & \\
Karies gigi & & \\
Ada karies & 112 & \\
Tidak ada karies & 100 & \\
\hline
\end{tabular}

Karakateristik subjek terlihat bahwa distribusi jenis kelamin laki-laki 47,5\% dan perempuan $52,4 \%$. Umur responden antara 8 sampai 12 tahun, distribusi usia sampel paling banyak 8-10, tahun yaitu $66,5 \%$. Pengukuran frekuensi konsumsi makanan kariogenik dilakukan dengan mengukur sering tidaknya anak mengkonsumsi ma- kanan kariogenik dalam sehari. Anak dengan frekuensi makanan kariogenik sering $72,6 \%$ dan pemeriksaan gigi hanya $33,5 \%$ yang teratur melakukan pemeriksakan gigi, dan pengatahuan anak tentang kesehatan giginya baik sebanyak $70,8 \%$ dan yang ada karier gigi sebanyak 52,8 \% dan anak yang tidak ada karier gigi terdapat $47,2 \%$.

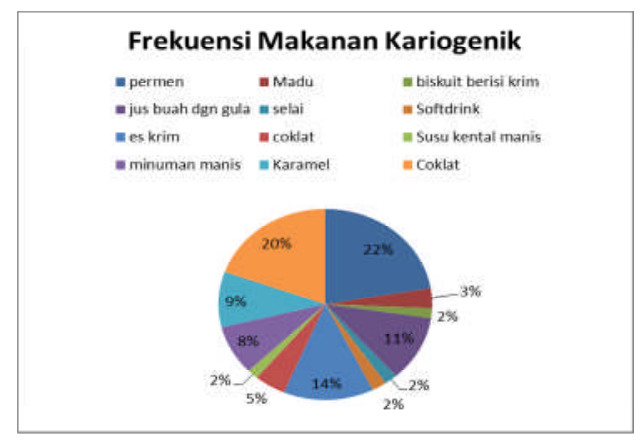

Gambar 1. Diagram Pie Frekuensi Konsumsi Makanan Kariogenik Anak SD Kota Bengkulu

Frekuensi konsumsi untuk tiap jenis makanan Kariogenik anak sekolah dasar
Kota Bengkulu tahun 2011. Jenis makanan kariogenik yang sering dikonsumsi murid 
Sekolah Dasar di Kota Bengkulu dengan frekuensi konsumsi lebih besar atau sama dengan 4 kali per hari adalah permen, jus buah dengan gula, es krim, karamel, coklat, dan minuman manis. Dari gambar 1 terlihat bahwa frekuensi konsumsi makanan kariogenik pada anak merupakan hasil akumulasi konsumsi berbagai jenis makanan kariogenik dalam sehari. Misal : seorang anak mengkonsumsi permen 1 kali, jus dengan gula 1 kali, susu kental manis 1 kali, biskuit berisi krim 1 kali, es krim 1 kali termasuk kategori frekuensi konsumsi sering.

\section{Analisis Bivariat}

Hasil analisis bivariat digunakan untuk melihat hubungan antara variabel independen dengan dependent, dapat dilihat pada tabel 2.

\section{Hubungan Jenis Kelamin dengan Karies Gigi Anak}

Hasil analisis hubungan antara jenis kelamin dengan karier gigi anak terdapat $60.9 \%$ anak dengan jenis kelamin laki-laki ada karies gigi, sedangkan anak yang berjenis kelamin perempuan $44,1 \%$ yang ada karies gigi. Hasil uji statistik menunjukkan bahwa $\mathrm{p}=0,021$ maka dapat disimpulkan ada perbedaan proporsi karies gigi antara anak yang berjenis kelamin laki-laki dan perempuan (ada hubungan yang signifikan antara jenis kelamin dengan karies gigi anak. Dari hasil analisis diperoleh nilai OR 1,974 (95\% CI : 1,142- 3,411) berarti anak yang berjenis kelamin laki-laki ada karier gigi 2 kali dibandingkan anak yang berjenis kelamin perempuan.

\section{Hubungan Umur dengan Karies Gigi Anak}

Hasil analisis hubungan antara umur dengan karier gigi anak terdapat $45.4 \%$ anak yang berumur 8-10 tahun yang ada karies gigi, sedangkan anak yang berumur 11-12 tahun beerjenis kelamin perempuan $44.1 \%$ yang ada karies gigi. Hasil uji statistik menunjukkan bahwa $\mathrm{p}=0.004$ maka dapat disimpulkan ada perbedaan proporsi karies gigi antara anak yang berumur $8-10$ tahun dan berumur 11-12 tahun, ada hubungan yang signifikan antara umur dengan karies gigi anak.

\section{Hubungan Pemeriksaan Gigi dengan Ka- ries Gigi Anak}

Hasil analisis hubungan antara Pemeriksaan gigi dengan karier gigi anak terdapat 59,6\% yang pemeriksaan gigi tidak teratur ada karies gigi, sedangkan anak yang pemeriksaan gigi teratur 39,4\% yang ada karies gigi. Hasil uji statistik menunjukkan bahwa $\mathrm{p}=0.009$ maka dapat disimpulkan ada perbedaan proporsi karies gigi antara anak dengan pemeriksaan gigi yang tidak teratur dan teratur (ada hubungan yang signifikan antara pemeriksaan gigi dengan karies gigi anak). Dari hasil analisis diperoleh nilai OR 2,263 (95\% CI : 1,264-4,053) berarti anak yang pemeriksaan gigi tidak teratur, ada karier gigi 4 kali dibandingkan anak yang pemeriksaan gigi teratur.

\section{Hubungan Frekuensi makanan Kariogenik dengan Karies Gigi Anak}

Salah satu penyebab terjadinya karies gigi adalah konsumsi makanan kariogenik. Konsumsi makanan kariogenik yang berulang terutama di antara waktu makan atau sebagai makanan selingan menyebabkan pembentukkan asam oleh plak dan kondisi ini lebih kariogenik (Husin, 2000).

Dari analisis pada tabel 3 dapat diketahui bahwa hasul analisis hubungan antara Frekuensi makanan kariogenik dengan karier gigi anak terdapat $92(59,7 \%)$ yang Frekuensi makanan kariogenik sering yang ada karies gigi, sedangkan anak yang Frekuensi makanan kariogenik tidak sering 20 (34,5\%) yang ada karies gigi. Hasil uji statistik menunjukkan bahwa $\mathrm{p}=0.002$ maka dapat disimpulkan ada perbedaan proporsi karies gigi antara anak dengan Frekuensi makanan kariogenik yang sering dan tidak sering (ada hubungan yang signifikan antara Frekuensi makanan ka- 
riogenik dengan karies gigi anak.Dari hasil analisis diperoleh nilai OR 2,819 (95\% CI : 1,502-5,294) berarti anak yang Frekuensi makanan kariogenik sering, ada karier gigi 2.819 kali dibandingkan anak yang Frekuensi makanan kariogenik tidak sering.

\section{Hubungan Pengetahuan dengan Karies Gigi Anak}

Pengetahuan kesehatan gigi merupakan kemampuan anak untuk men-jawab pertanyaan tentang kesehatan gigi yang diukur dengan menjumlahkan skor jawaban yang benar. Tingkat pengetahuan kesehatan gigi dihitung dengan membandingkan skor total terhadap median skor. Pengetahuan kesehatan gigi berkaitan langsung dengan konsumsi makanan kario- genik yang menyebabkan karier gigi. Menurut Notoatmodjo (2003) pengetahuan atau kognitif merupakan domain yang sangat penting dalam membentuk tindakan seseorang (overt behaviour). Anak yang mempunyai pengetahuan kesehatan gigi baik, ada karir gigi ternyata 43,6 \%, sedangkan pada anak yang pengetahuan kesehatan giginya tidak baik, 64.2\% ada karier gigi. Analisis secara statistik dengan chi square tests menunjukkan adanya hubungan antara pengetahuan gizi dengan karies gigi pada taraf signifikan $\mathrm{p}=0,004$. Dari hasil analisis diperoleh nilai OR 0,431 (95\% CI : 0,247- 0.751) berarti anak yang pengetahuan gizi tidak baik ada karier gigi 2.819 kali dibandingkan anak yang pengetahuan gizi baik ada karier gigi.

Tabel 2. Hubungan jenis kelamin, umur, pemeriksaan gigi, frekuensi makanan kariogenik, pengetahuan dengan karier gigi

\begin{tabular}{|c|c|c|c|c|c|c|}
\hline \multirow[t]{2}{*}{ Variable } & \multicolumn{2}{|c|}{ Karier gigi } & \multirow[t]{2}{*}{ Total $(\mathrm{N})$} & \multirow[t]{2}{*}{$\mathrm{P}$} & \multirow[t]{2}{*}{ OR } & \multirow[t]{2}{*}{ IK $95 \%$} \\
\hline & $\begin{array}{l}\text { Ada karier } \\
(\mathrm{n}=112)\end{array}$ & $\begin{array}{l}\text { Tidak karier } \\
(\mathrm{n}=100)\end{array}$ & & & & \\
\hline \multicolumn{7}{|l|}{ Jenis Kelamin } \\
\hline Laki-laki & $67(60.9 \%)$ & $43(39.1 \%)$ & $110(100,0 \%)$ & \multirow{2}{*}{$0.021 * *$} & \multirow{2}{*}{1.974} & $1.142-3.411$ \\
\hline Perempuan & $45(44.1 \%)$ & $57(55.9 \%)$ & $102(100,0 \%)$ & & & \\
\hline \multicolumn{7}{|l|}{ Umur } \\
\hline $8-10$ tahun & $64(45.4 \%)$ & $77(54.6 \%)$ & $142(100 \%)$ & \multirow[t]{2}{*}{$0.004 * *$} & \multirow[t]{2}{*}{0.398} & \multirow[t]{2}{*}{$0.219-0.724$} \\
\hline 11-12 tahun & $48(67.6 \%)$ & $23(32.4 \%)$ & $71(100 \%)$ & & & \\
\hline \multicolumn{7}{|l|}{ Pemeriksaan gigi } \\
\hline Tidak teratur & $84(59.6 \%)$ & $57(40.4 \%)$ & $141(100.0 \%)$ & \multirow{3}{*}{$0.009 * *$} & 2.263 & \multirow[t]{2}{*}{$1.264-4.053$} \\
\hline Teratur & $28(39.4 \%)$ & $43(60,6 \%)$ & $71(100,0 \%)$ & & & \\
\hline \multicolumn{6}{|c|}{ Frekuensi maknan kariogenik } & \\
\hline Sering & $92(59.7 \%)$ & $62(40.3 \%)$ & $154(100,0 \%)$ & \multirow{3}{*}{$0.002 * *$} & 2.819 & \multirow[t]{2}{*}{$1.502-5.294$} \\
\hline Tidak sering & $20(34.5 \%)$ & $38(65.5 \%)$ & $58(100,0 \%)$ & & & \\
\hline \multicolumn{5}{|l|}{ Pengetahuan } & & \multirow{3}{*}{$0.247-0.751$} \\
\hline Baik & $21(52,5 \%)$ & $19(47,5 \%)$ & $40(100,0 \%)$ & \multirow{2}{*}{$0,004 * *$} & \multirow[t]{2}{*}{0.431} & \\
\hline Tidak baik & $7(41,2 \%)$ & $10(58,8 \%)$ & $17(100,0 \%)$ & & & \\
\hline
\end{tabular}

Keterangan : Uji statistik menggunakan chi square. *Bermakna $(\mathrm{p}<0,05)$

\section{Analisis Multivariat}

Analisis multivariat regresi logistik ganda dilakukan terhadap variabel-variabel yang pada analisis bivariat memiliki kemaknaan cukup kuat ( $p$ value $<0,25$ ) serta diduga memiliki kontribusi penting bagi karier gigi anak. Uji ini dimaksudkan untuk mencari model yang paling cocok untuk mengetahui faktor yang paling dominan diantara variabel indevenden yang berhubungan dengan variabel dependen. Tahapan pertama dalam analisis multivariat ini adalah memilih variabel kandidat multivariat. Dalam pemilihan variabel kandidat dilihat dari hasil analisis bivariat antara variabel indevenden dan Variabel 
dependen. Hasil analisis multivariat dapat

dilihat pada tabel berikut ini:

Tabel 3. Tahap Pertama dari Hasil analisis Multivariat Regresi logistik ganda antara Jenis kelamin Umur, Pemeriksaan Gigi, Frekuensi Makanan kariogenik, Pengetahuan dengan Karier Gigi Anak Sekolah Dasar di Kota Bengkulu

\begin{tabular}{lcccc}
\hline \multicolumn{1}{c}{ Variabel } & B & OR & P value & 95\% CI \\
\hline Jenis Kelamin & -0.380 & 0.684 & 0.192 & $0.387-1.210$ \\
Umur & 0.362 & 1.436 & 0.068 & $0.973-2.120$ \\
Pemeriksaan Gigi & -0.908 & 0.403 & 0.004 & $0.217-0.749$ \\
Frekuensi Makanan Kariogenik & 0.570 & 1.769 & 0.087 & $0.920-3.402$ \\
Pengetahuan & 0.690 & 2.002 & 0.038 & $1.039-3.860$ \\
Konstan & -4.244 & 0.014 & 0.044 & \\
\hline
\end{tabular}

-2log Likehood 273.424 P value 0.001 G=19.791

Menunjukkan dilakukan evaluasi masing-masing variabel dengan melihat nilai P pada uji statistik Wald, jika $\mathrm{p}$ value > 0.05 dikeluarkan dari model, selain itu juga mempertim-bangkan substansi. Dari tabel diatas variabel umur dan frekuensi makanan kariogenik memiliki p value $>0.05$, namun secara substansi variabel umur dan fekuensi makanan kariogenik memiliki kontribusi dalam adanya karier gigi, maka variabel tersebut dipertahankan dalam model, dengan dilakukan pengeluaran variabel secara bertahap. Berdasarkan hasil tersebut diketahui variabel jenis kelamin mempunyai nilai $\mathrm{p}$ value (0.192), sehingga dikeluarkan dari model, selanjutnya dilakukan analisis multivariat seperti langkah se-belumnya

Tabel 4. Tahap Terakhir dari Hasil Analisis Multivariat Regresi logistik Ganda antara Jenis kelamin, Umur, Pemeriksaan Gigi,Frekuensi Makanan kariogenik, Pengetahuan dengan Karier Gigi Anak Sekolah Dasar di Kota Bengkulu

\begin{tabular}{lcccc}
\hline Variabel & B & OR & P value & 95\% CI \\
\hline Umur & 1.436 & 1.439 & 0.067 & $0.975-2.126$ \\
Pemeriksaan Gigi & 0.403 & 0.401 & 0.004 & $0.217-0.742$ \\
Frekuensi Makanan Kariogenik & 1.769 & 1.775 & 0.083 & $0.927-3.400$ \\
Pengetahuan & 2.002 & 1.911 & 0.050 & $1.001-3.648$ \\
Konstan & -4.385 & 0.012 & 0.038 & \\
\hline
\end{tabular}

-2log Likehood 275.138 P value 0.001 G= 18.077

Variabel pemeriksaan gigi, pengetahuan mempunyai $p$ value $<0.05$, berarti variabel tersebut berhubungan secara signifikan dengan adanya karier gigi pada a- nak di Kota Bengkulu. Langka berikutnya melihat perubhan nilai OR sebelum dan sesudah variabel jenis kelamin dikeluarkan.

Tabel 5. Perubahan Nilai OR sebelum dan sesudah variabel status Jenis kelamin dikeluarkan

\begin{tabular}{lccc}
\hline \multicolumn{1}{c}{ Variabel } & OR & OR & Perubahan OR \\
& $\begin{array}{c}\text { Model dengan variabel Jenis } \\
\text { Kelamin }\end{array}$ & $\begin{array}{c}\text { Model tanpa variabel Jenis } \\
\text { Kelamin }\end{array}$ & \\
\hline Umur & 1.436 & 1.439 & $0.3 \%$ \\
Pemeriksaan Gigi & 0.403 & 0.401 & $0.2 \%$ \\
Frekuensi Makanan Kariogenik & 1.769 & 1.775 & $0.6 \%$ \\
Pengetahuan & 2.002 & 1.911 & $9.1 \%$ \\
\hline
\end{tabular}

Variabel yang paling dominan berhubungan dengan adanya karies gigi pada anak sekolah dasar di Kota Bengkulu dari keempat variabel, yaitu pengetahuan, frekuensi makanan kariogenik, umur dan pemeriksaan gigi, maka variabel pengeta- 
huan merupakan variabel yang paling dominan berhubungan dengan karies gigi anak sekolah dasar di Kota Bengkulu, diikuti oleh variabel frekuensi makanan karies gigi, umur dan pemeriksaan gigi.

\section{PEMBAHASAN}

\section{Hubungan Jenis Kelamin dan Karies Gigi}

Lebih banyak dialami anak perempuan yaitu $52.4 \%$ dari total keseluruhan sampel, hasil ini sesuai dengan penelitian Marhamah (2002) bahwa prevalensi kejadian karies gigi lebih banyak pada anak perempuan dibandingkan laki-laki karena pola dan perilaku makan yang berbeda.

Hasil ini sesuai dengan penelitian Marhamah (2002) bahwa prevalensi kejadian karies gigi lebih banyak pada anak perempuan dibandingkan laki -laki karena pola dan perilaku makan yang berbeda pada anak laki-laki dibandingkan pada anak perempuan.

\section{Hubungan Umur dengan Karies Gigi}

Prevalensi karies gigi pada anak berumur 9-10 tahun lebih tinggi daripada anak berumur 11-12 tahun yaitu $66,5 \%$ dibandingkan 33,5\%. Dari hasil uji statistik menunjukkan ada hubungan umur dengan karies gigi pada anak sekolah dasar di Kota Bengkulu. Hasil ini sejalan dengan Penelitian yang dilaksanakan oleh Agus (1999) pada siswa SD, SLPT dan SLTA di Kodya Bandung juga menunjukkan prevalensi karies gigi yang masih cukup tinggi yaitu $89,4 \%$ pada siswa umur 9 sampai 12 tahun. Pada penelitian lain yang dilakukan oleh Rahina, dkk (2002) pada anak-anak sekolah dasar di Kabupaten Buleleng Bali menunjukkan prevalensi karies gigi sebesar $88,35 \%$, hal ini terjadi karena masih kurangnya kesadaran anak untuk menjaga kesehatan gigi dan mengkonsumsi makanan yang tepat dan pembentukan gigi tetap sudah hampir lengkap sehingga bila karies terjadi pada gigi sulung dan tanggal akan tergantikan oleh gigi tetap yang baru dan sehat (Tomasowa, 1995).

\section{Hubungan Frekuensi Makanan dengan Ka- ries Gigi}

Makanan kariogenik yang sering dikonsumsi anak-anak Sekolah Dasar Kota Bengkulu (dengan frekuensi konsumsi $>4$ kali dalam sehari) adalah permen, jus buah + gula, es krim, karamel, coklat dan minuman manis. Makanan-makanan seperti ini banyak dijual di warung sekolah, pedagang- pedagang di lingkungan sekolah maupun warung-warung di sekitar rumah mereka. Dari 212 sampel yang diteliti terdapat 72,6\% (154 anak) yang sering mengkonsumsi makanan kariogenik. Hal ini sesuai dengan pernyataan Arisman (2004) bahwa anak usia sekolah sudah biasa membeli makanan jajanan sendiri dan makanan yang disukai adalah makanan yang banyak mengandung gula. Gula dalam makanan yang memiliki waktu retensi panjang pada kavitas gigi memiliki peran utama dalam pembentukkan karies gigi. Semakin sering anak mengkonsumsi makanan yang mengandung karbohidrat terutama sukrosa semakin lama keadaan asam dalam mulut sehingga makin besar kemungkinan demineralisasi email (Haryani, 2002).

Analisis statistik dengan Chi Squere test menunjukkan ada hubungan frekuensi konsumsi makanan kariogenik dengan karies gigi anak. Hasil ini sesuai dengan penelitian Kastella (2004) yaitu ada hubungan konsumsi makanan kariogenik dengan karies gigi anak. Hal ini dipertegas juga oleh hasil penelitian Vipeholm yang menunjukkan adanya hubungan karies dengan frekuensi makanan/minuman kariogenik (Suwelo, 1992). Pada usia sekolah, anak sudah mempunyai uang saku dan mereka bisa membeli jajanan yang diinginkan di warung sekolah atau pedagang makanan di sekitar sekolah (Prawirohartono, 1997). Makanan yang disukai anak antara lain permen, kue berisi krim, kue kering dan minuman manis yang dapat dengan mudah menimbulkan karies (Arisman, 2004). 
Penyebab karies gigi adalah konsumsi makanan kariogenik. Husin (2000) proses awal karies gigi dimulai dari pembentukkan asam di dalam plak yang terjadi bila karbohidrat yang dikonsumsi difermentasi oleh bakteri. Semakin lama makanan berada dalam rongga mulut semakin lama pula gigi terkondisi untuk terjadinya karies gigi. Frekuensi dan jenis karbohidrat seperti permen, gula, makanan dan kue ringan, coklat bersifat sangat kariogenik. Kebiasaan mengkonsumsi makanan kariogenik yang sering sebagai makanan selingan membuat kondisi asam dalam plak pada kondisi puncak dan memudahkan proses demineralisasi gigi yang berlanjut ke karies gigi. Hasil penelitian ini sesuai dengan penelitian Kastella (2003) di SD di Kota Bengkulu yaitu anak-anak sering mengkonsumsi makanan manis tiap hari pada penjual makanan di sekolah maupun warung di sekitar tempat tinggalnya, sehingga ada hubungan konsumsi makanan kariogenik dengan karies gigi pada anak. Menurut Beck (2000), empat faktor yang penting dalam pencegahan karies gigi adalah Pemberian flourida untuk menguatkan gigi, Sikat gigi yang efisien untuk melepaskan dental plaque, Perubahan diet, Perawatan gigi yang teratur.

Tujuan pada perubahan diet adalah untuk mengurangi jumlah maupun frekuensi konsumsi gula pasir (sukrosa). Langkah-langkah perubahan diet yang benar adalah: Memilih jenis makanan yang bebas gula, Tidak menambahkan gula kedalam minuman, Tidak menambahkan ekstra gula pada makanan bayi, Mengkonsumi buah, jagung, biskuit yang asin sebagai camilan untuk menggantikan makanan yang manis, Menghindari makanan manis yang lengket, Bila ingin makanan manis sebaiknya dimakan bersama-sama atau sesudah bersantap.

\section{Hubungan Pengetahuan Kesehatan Gigi de- ngan Karies Gigi}

Sebanyak 70,8\% pengetahuan kesehatan giginya baik dan $29.2 \%$ pengetahuannya tidak baik. Menurut Notoatmodjo
(2003) pengetahuan merupakan hasil dari tahu dan merupakan domain yang sangat penting untuk membentuk tindakan seseorang. Perilaku yang didasari oleh pengetahuan akan lebih langgeng daripada perilaku yang tidak didasari pengetahuan. Berdasarkan teori Rogers dan Schoemaker (1974) proses terbentuknya perilaku baru pada anak sekolah dasar masih sulit dilakukan karena proses terbentuknya perilaku harus melalui proses yang berurutan yang dimulai dari kesadaran mengetahui stimulus, ketertarikan kepada stimulus, penilaian baik dan tidaknya stimulus, mencoba berperilaku baru dan mengadopsi perilaku baru sesuai dengan pengetahuan, kesadaran dan sikapnya terhadap stimulus yang cukup berat dilalui oleh anak sekolah dasar. Perilaku terbentuk melalui suatu proses tertentu dan berlangsung dalam interaksi manusia dengan lingkungannya.

Anak sekolah dasar yang diteliti pengetahuan kesehatan giginya cukup baik, tetapi motivasi, keterampilan, kemampuan, kesempatan dan dukungan sosial pada anak masih kurang sehingga belum terbentuk perilaku kesehatan gigi yang baik. Anak yang mempunyai pengetahuan kesehatan gigi baik $56 \%$ tidak sering mengkonsumsi makanan kariogenik, sedangkan pada anak yang berpengetahuan tidak baik $75 \%$ tidak sering mengkonsumsi makananan kariogenik. Bila dilihat dari frekuensi konsumsi makanan kariogenik, persentase anak yang tidak sering mengkonsumsi ternyata lebih tinggi pada anak yang berpengetahuan tidak baik, yaitu $75 \%$ dibandingkan $56 \%$.

\section{Hubungan Pemeriksaan Gigi Dengan Ka- ries Gigi}

Analisis statistik dengan Chi Squere test menunjukkan ada hubungan Pemeriksaan gigi dengan karies gigi anak. Perilaku kesehatan yang positif tersebut merupakan salah satu sasaran pembangunan kesehatan yaitu berperilaku hidup sehat (Hoesin, 2003). Menurut Machfoedz dan Zein (2005) waktu menyikat gigi yang 
tepat adalah sesudah makan dan sebelum tidur dan pada anak-anak Sekolah Dasar di Kota Bengkulu 33,5\% yang teratur pemeriksaan gigi yaitu menyikat gigi dengan frekuensi kurang dari 3 kali sehari dan rutin memeriksakan gigi dan $66.5 \%$ tidak teratur melakukan pemeriksaan gigi. Hal ini terlihat pada saat dilakukan pemeriksaan kesehatan gigi. Banyak anak yang takut diperiksa giginya. Selain itu masih kurang optimalnya peran UKGS dan motivasi orang tua untuk membentuk perilaku memelihara kesehatan gigi yang baik secara terus menerus sehingga menjadi suatu kebiasaan yang positif berpengaruh secara tidak langsung terhadap kejadian karies gigi pada anak. Perilaku pada sebagian besar manusia adalah operant response yaitu respon yang timbul dan berkembang kemudian diikuti oleh stimulus atau perangsang tertentu. Misalnya pada anak yang rajin menggosok gigi setelah makan dan sebelum tidur akan mendapat rewards seperti boleh membeli es krim atau coklat (Notoatmodjo, 2003). Hal ini akan mengakibatkan perilaku atau tindakan tersebut cenderung akan sering dilakukan sehingga terbentuk perilaku yang positif. Perilaku terbentuk melalui suatu proses tertentu dan berlangsung dalam interaksi manusia dengan lingkungannya. Rogers (1974), anak akan berperilaku kesehatan gigi yang baik dimulai dari adanya kesadaran pada diri anak akan pentingnya menjaga kesehatan gigi yang akhirnya berlanjut pada tahap adopsi perilaku sesuai dengan pengetahuan, kesadaran, dan sikapnya terhadap stimulus.

Berdasarkan teori Green (1990) dari faktor predisposisi maka, pengetahuan kesehatan gigi anak baik tetapi kebiasaan, kemampuan, keterampilan, sikap dan motivasi anak masih kurang, faktor pendukung yaitu alat (sikat gigi dan perlengkapan), tersedia karena semua anak mengatakan mempunyai sikat gigi sendiri, dan faktor penguat/pendorong yaitu dukungan orang tua maupun guru sekolah sebagai orang-orang yang terdekat dengan anak masih perlu ditingkatkan untuk mendorong terbentuknya perilaku kesehatan gigi yang lebih baik. Berdasarkan penyebab perubahan perilaku pada pendidikan gizi dan kesehatan menurut Soekirman dan Tarwotjo (1986), perubahan perilaku terbentuk bila didasari kesiapan psikologis pada anak, tekanan positif dari group tertentu dan dukungan lingkungan fisik dan ekonomi. Pada anak sekolah dasar belum ada kesiapan psikologis untuk mengubah perilaku, masih perlunya tekanan positif dari group tertentu dalam hal ini guru dan orang tua serta lingkungan fisik dan ekonomi yang mencakup ketersediaan fasilitas dan peralatan. Strategi perubahan perilaku menurut WHO meliputi menggunakan kekuasaan atau dorongan, pemberian informasi dan diskusi partisipasi.

Faktor yang paling dominan Karies Gigi terhadap Jenis Kelamin, umur, pemeriksaan gigi, pengetahuan. Analisis untuk mengetahui faktor yang paling dominan diantara variabel-variabel yang masuk dalam model multivariat yaitu memiliki nilai $\mathrm{P}$ value $<0,25$ yaitu umur, pengetahuan gigi dan pemeriksaan gigi. Namun menurut pertimbangan variabel substansi frekuensi makanan kariogenik, masuk kedalam model multivariat. Frekuensi makanan karies frekuensi makanan kariogenik frekuensi makanan kariogenik masuk dalam model karena secara substansi kedua variabel tersebut berhubungan terhadap karier gigi. Pengeluaran variabel secara bertahap dimulai dari variabel dengan $p$ value terbesar. Variabel jenis kelamin dikeluarkan dari model selanjutnya setelah dilakukan analisis multivariat seperti langkah sebelumnya. Dari model multivariat dapat disimpulkan variabel yang paling dominan adalah pengetahuan gigi, diikuti oleh variabel frekuensi makanan karies gigi, umur dan pemeriksaan gigi.

\section{KESIMPULAN}

Dari hasil penelitian dan pembahasan yang telah dikemukakan diatas dapat diambil kesimpulan sebagai berikut: Sebagian besar responden sering $(72,6 \%)$ 
mengkonsumsi makanan, dan tingkat pengetahuan kesehatan gigi anak menunjukkan $70,8 \%$ pengetahuannya baik. Ada hubungan frekuensi konsumsi makanan kariogenik dengan karies gigi anak dengan nilai $p$ value $0.002<0,05$ ), dan ada hubungan pengetahuan kesehatan gigi anak dengan karies gigi $p$ value $0.004<0,05$, serta variabel yang paling dominan yang berhubungan karies gigi pada anak sekolah dasar pada sekolah dasar yaitu pengetahuan, frekuensi makanan kariogenik, frekuensi makanan kariogenik, umur dan pemeriksaan gigi.

Berdasarkan hasil penelitian yang telah disimpulkan diatas, peneliti menyaran-

\section{DAFTAR KEPUSTAKAAN}

Almatsier, S. (2001) Prinsip Dasar Ilmu Gizi. Jakarta : Gramedia.

Atmarita \& Fallah, T.S. (2004). Analisa Situasi Gizi dan Kesehatan Masyarakat. Makalah disajikan pada Widyakarya Nasional Pangan dan Gizi VIII, Jakarta.

Azwar, S. (2008) Pengantar Psikologi Inteligensi.Yogyakarta:Pustaka Pelajar.

Baker-Henningham, H., \& Grantham-McGregor, S. (2009) Gizi dan Perkembangan Anak. In : Gibney,M.J., Margetts,B.M., Kearney, J.M. \& Arab, L (Eds). Gizi Kesehatan Masyarakat. Jakarta: EGC

Berkman, D.S., Black, M.M., Gilman, R.H., Lescano, A.G.,\&Lopez, S.L. (2002) Effects of Stunting, diarrhoeal disease, and parasitic infection during infancy on cognition in late childhood: a follow-up study. The Lancet Vol 359, 564-571

BPS (2008) Lombok Timur Dalam Angka. Selong: BPS.

Depkes RI. (2004) Petunjuk Teknis Standar Pelayanan Minimal Bidang Kesehatan di Kabupaten/Kota, keputusan Menteri Kesehatan RI Nomor 1091/Menkes/SK/X/2004. Jakarta: Depkes RI.

Depkes RI. (2005) Klasifikasi Status Gizi Anak Bawah Lima Tahun Keputusan Menteri Kesehatan RI Nomor : 920/ Menkes / SK / VIII /2002, Jakarta: Depkes RI.

Depkes RI. (2007) Pedoman Pelaksanaan Stimulasi, Deteksi dan Intervensi Dini Tumbuh Kembang Anak Ditingkat Pelayanan Kesehatan Dasar. Jakarta: Depkes RI.

Depkes RI. (2008) Riset Kesehatan Dasar 2007. Jakarta: Balibangkes. kan kepada pihak sekolah, perlu adanya tindak lanjut penanganan dari petugas gizi terhadap pencegahan karies gigi melalui konsumsi makanan yang tepat secara terpadu dengan program UKS/UKGS. Perlu digalakkan KIE (Komunikasi -InformasiEdukasi) di sekolah bekerjasama dengan penanggung jawab UKS/UKGS, terutama pemberian informasi yang tepat dan jelas tentang makanan kariogenik sebagai penyebab terjadinya karies gigi, dan peningkatan peran serta orang tua untuk memberikan dorongan atau motivasi pada anak untuk memperbaiki perilaku konsumsi makanan kariogenik dan perilaku menjaga kesehatan gigi yang baik.

Dinkes Lotim. (2006) Laporan Tahunan Program Perbaikan Gizi Masyarakat Kabupaten Lombok Timur 2005. Selong: Dinkes

Georgieff, M.K. (2006) Early Brain Growth: Macronutrients for the Developing Brain.NeoReviews.org

Georgieff, M.K. (2007) Nutrition and the Developing Brain : Nutrient Priorities and Measurement. Am J Clin Nutr, 614S-620S.

Gibson, R. S. (2005) Principles of nutritional assessment. $2^{\text {nd }} e d$. New York : Oxford University.

Gordis, L. (2004) Epidemiology-3 $3^{\text {rd }}$ ed.Philadelpia.Elsevier Saunders.

Grantham-McGregor, S. (1995) A Review of Studies of the Effect of Severe Malnutrition on Mental Development. J.Nutr, 2233S-2237S.

Grantham-McGregor, S., Fernald, L., \& Sethuraman, K. (1999) Effects of Health and Nutrition on Cognitive and Behavioural Development in Children in the First three years of life. Food and Nutrition Bulletin vol. 20, no. 1, 53-74.

Grantham-McGregor, S.M., Powell, C.A., Walker, S.P., Himes, J.H.(1991) Nutritional supplementation, psychosocial stimulation, and mental development of stunted children :The Jamaican study. Am,J Clin Nutr, 54:642-8

Hadi, H. (2005) Beban Ganda Masalah Gizi dan Implikasinya Terhadap Kebijakan Pembangunan Kesehatan Nasional, Pidato Pengukuhan Jabatan Guru Besar pada Fakultas Kedokteran Universitas Gadjah Mada. Yogyajarta.

Hurlock, E. (2008) Perkembangan Anak Jilid I Edisi Keenam. Jakarta: Erlangga.

Judarwanto, W. (2005) Tampilan Klinis dan Komplikasai KEP. [Internet], Available from 
$:<$ http://www.pdpersi.co.id/. [Accessed 16 Juli 2009].

Lemeshow, S.,Hosmer Jr,D.W., Klar, J., Lwanga, S.K. (1997) Besar Sampel dalam Penelitian Klinis. Yogyakarta. Gadjah Mada University Press.

Liu, J., Raine, A., Venables, P., \& Mednick, S. (2004) Malnutrition at Age 3 Years and Externalizing Behavior Problems at Age 8, 11, and 17 Years. Am J Psychiatry, 2005-2013.

LPSP3 UI, Buku Petunjuk Penggunaan Test Wechsler Preschool and Primary Scale of Intelligence. Jakarta.

Mendez, M., \& Adair, L. (1999) Severity and Timing of Stunting in the First Two Years of Life Affect Performance on Cognitive Tests in Late Childhood. J.Nutr, 1555-1562.

Monks, F., Knoers, A., \& Haditono, S. (2006) Psikologi Perkembangan Pengantar dalam berbagai bagiannya. Yogyakarta: Gadjah Mada University Press.

NCCP (1999) Poverty and Brain Development in Early Childhood. New York: NCCP

Purwandari, H., Prawirohartono,E.P.,\& Hartati, S. (2008) Usia penyapihan dam hubungannya dengan inteligensia pada siswa TK. Jurnal Gizi Klinik Indonesia, :5(1):21-27

Puskesmas Dasan Lekong (2009) Laporan Tahunan 2008. Dasan Lekong; Puskesmas

Sastroasmoro S \& Ismael, S (1995) Dasar-dasar Metodologi Penelitian Klinis. Jakarta: Bagian Ilmu Kesehatan Anak FKUI
Schaible, U.E \& Kauffman S.H.E (2007) Malnutrition and Infection: Complex Mechanisms and Global Impacts. [Internet], Available fromt $<$ http://www.plosmedicine.org $>$ [Accessed 15 Mei 2009)

Singh, M. (2003) Nutrition, brain and environment: how to have smarter babies? Indian Pediatr, 40: 213-220

Soekirman (2000) Ilmu Gizi dan Aplikasinya untuk Keluarga dan Masyarakat. Jakarta: Departemen Pendidikan Nasional.

Soetjiningsih (1995) Tumbuh Kembang Anak. Jakarta: EGC.

Sophia, E (2009) Maksimalkan Potensi Anak dan Bayi.[Internet], Available from: http://medicastore.com/ [Accessed 6 Juli 2009)

Suhartono, Boediman,D.,\& Castro,T. (2008)Pertumbuhan dan perkembangan anak gizi masa lalu di kabupaten Tanggamus Provinsi Lampung. Jurnal Gizi Klinik Indonesia 2008:5(1):41-48

Unicef (1998) The State of The World's Children.Oxford University Press.

Watanabe, K., Flores, R., Fujiwara, J., \& Tran, L. (2005) Early Childhood Development Intervention and Cognitive Development of Young Children in Rural Vietnam. J.Nutr, 1918-1925.

WHO (2006) WHO Child Growth Standards. Geneva; WHO Press 